\title{
Modern Chinese Students Studying in Japan and Xiangshan Society
}

\author{
Peng Jiao \\ College of Humanities \\ Jinan University \\ Zhuhai, China
}

\begin{abstract}
The defeat of the Sino-Japanese war in 1894 greatly changed the Chinese people's ideas and thoughts. Chinese people realize that Japan has developed because of sending students abroad. Domestic media called on the government to send students abroad. In 1902, the Qing government implemented a new policy requiring all localities to send students to Japan. The number of students going to Japan had soared. In this trend, a large number of Xiangshan students followed it and also went to Japan. After the students returned to their hometown, they ran a newspaper and organized societies for revolutionary propaganda, and also managed education business in hometown to expand Esperanto; these activities have affected the changes of modern Xiangshan society.
\end{abstract}

Keywords-modern China; students studying in Japan; Xiangshan society

\section{INTRODUCTION}

In the Sino-Japanese War of 1894, the Qing government was defeated by her past "student" Japan. It shocked Chinese people. Chinese began to examine the situation of the rise of Japan. They found that studying abroad was an important factor in the development of Japan, so they called on the government to send students to study in Japan. After the Qing government's new policy, the number of oversea students in the Qing Dynasty surged. The academic circles have done a lot of research on it, so there is no need to enumerate them. Guangdong is located in the southeast coast, earlier affected by overseas. They were positive in the new policy of sending students to study abroad. $70 \%$ of the young children abroad to the United States were from Guangdong. It is because of that the Qing government issued an edict calling local governments to send students to Japan. And the number of Guangdong students abroad to Japan surged, as well as that of Xiangshan students. However, there is not much research on Xiangshan and Guangdong students abroad to Japan. 1 Previous studies have paid little attention to the role of oversea students in the local society, which is the starting point of this study.

\section{SituAtion OF XIANGSHAN StUdENTS StUdying IN JAPAN}

The Sino-Japanese war ended with the failure of the Qing Dynasty. A great country was defeated by a tiny small country. China signed Treaty of Shimonoseki. We ceded territory and paid indemnities to Japan. It greatly shocked Chinese and aroused our reflection. This kind of reflection is based on the re-examination of Japan, which greatly changed our people's ideas and thoughts. Chinese have come to realize that the development of Japan in just a few decades was due to sending students to study abroad. Therefore, domestic media called on the government to send students to study in Japan. Governors including Zhang Zhidong advocated sending students to study abroad. He vigorously advocated sending students to study abroad in his Encourage to Study Abroad published in April 1898.

To study in Japan for one year is better than to study in Western countries for five years. Zhao Yingping said: "to see something once is better than to hear about it a hundred times". To study in foreign country for one year is better than to study in China for three years. It is the statement of Mencius. Japan is a small country. But why is it so developed? Ito Hirobumi, Yamagata Aritomo, Enomoto Takeaki and Mutsu Munemitsu were all students studying abroad twenty years ago. They were angry about the oppression of Western countries. So, they called upon more than a hundred of students to study politics, commerce, art of war and so on in Germany, French, England and other developed countries. They used them after they came back. After reform, they made a success. ${ }^{1}$

Zhang Zhidong emphasized that it is better to study in Japan than to study in Western countries.

They thought to study in Japan was better than to study in Western countries. First, it's short and save traveling expense. Second, it's near China and easy to investigate. Third, the language is similar to Chinese. It is easy to study. Fourth, western books are complicated. Eastern people have eliminated and altered some unimportant parts. The folk and customs between China and Japan are similar, so it is easy for us to learn from. It will yield twice the result with half the effort. $^{2}$

It was not only the opinion of Zhang Zhidong but also the consensus of a considerable number of the upper-class governors.

1 The author only sees it in Gao Long's paper: Analysis of Guangdong Students Studying in Japan at the end of Qing Dynasty. (Journal of Shangqiu Normal University, $7^{\text {th }}$ Issue, 2012) 
For Zhang Zhidong's opinion, the emperor issued an edict:

Zhang Zhidong's idea in Encourage to Study Abroad is pertinent and takes firm root among the academic circle. It is of great advantage. I plan to duplicate 40 copies and ask the Privy Council to issue to the civil and military governors of all provinces. Let them make public and persuade people. By this, tell people what is the most important.

It was issued to the civil and military governors and asked them to publish across the country.

Kang Youwei also made suggestion to the Emperor Guangxu to send students to study in Japan in his memorial Please Translate More Japanese Books and Send Students to Japan.

Only Japan is near us, and the traveling expense is low. Send students to study in Japan and train talents in a short time. I heard someone going to Japan to study at their expenses. They went through the procedures by themselves and at their own expenses, so the governments take no trouble to do it for them. But now our schools were badly in need of teachers. So we have to select excellent personnel to study in Japan. It will be good for us if we enroll new students to our schools. $^{3}$

Some provinces began to send government-sponsored students to Japan. But Guangdong did not send a group of students to Japan, only at their own expense to Japan. In some historical data, we can see Guangdong students and even Xiangshan students going to study in Japan. Fang Zhaoying's List of Oversea Students at the End of Qing Dynasty has recorded some. And some mentioned has already graduated: ${ }^{4}$

TABLE I. LIST OF OVERSEA STUDENTS AT THE END OF QING DYNASTY

\begin{tabular}{|c|c|c|c|c|c|}
\hline Name & Age & Native place & Enrollment time & $\begin{array}{c}\text { Graduation } \\
\text { date }\end{array}$ & Working unit \\
\hline Wei Rucong Shuping & 35 & Guangdong Xiangshan & Nov. 1924 & Mar. 1928 & $\begin{array}{l}\text { Probationary Sergeant in the } \\
\text { first wing of Guards Rifle } \\
\text { Division }\end{array}$ \\
\hline Zheng Huaxing Changguang & 22 & Guangdong Xiangshan & Feb. 1924 & Jun. 1928 & Sericulture Institute \\
\hline Zheng Rui Geyun & 21 & Guangdong Xiangshan & Feb. 1924 & Jun. 1928 & Sericulture Institute \\
\hline Yang Yuxian Jiliang & 36 & Guangdong Xiangshan & May 1924 & Nov. 1924 & $\begin{array}{l}\text { Hongwen Speed-up Normal } \\
\text { College }\end{array}$ \\
\hline
\end{tabular}

In "Table I", above four students all went to Japan in 1898. Wei Rucong was sent by the army. Zheng Huaxiong and Zheng Rui graduated from Sericulture Institute. They were sent by local department or organizations. Yang Yuxian graduated from speed-up school.

In Volume 16 of Imperial Xu'ai Essays, the Sangzhong School recorded Japanese Class Regulations for Chinese Students. It has mentioned the number of students and their native places:
Meiji thirty-two years (1899), enrolled in March

Zheng Kangqi from Xiangshan, Guangzhou, Guangdong ${ }^{5}$

Zheng Kangqi's identity was not mentioned here.

The book of Fang Zhaoying also mentioned some Xiangshang students going to Japan to study military at their own expenses: such as the "Table II"

TABLE II. Xiangshang Students Going to JaPAn to Study Military at Their Own ExPEnses

\begin{tabular}{|l|l|l|l|l|l|}
\hline Tang Shouqi Shuyun & 20 & Guangdong Xiangshan & May 1927 & Self-paying & Chengcheng School Land Force \\
\hline Su Zigu Lutian & 18 & Guangdong Xiangshan & Aug. 1928 & Self-paying & Chengcheng School Land Force \\
\hline
\end{tabular}

In 1902, the Qing government implemented the new policy and asked the local governments to send students abroad. Tao Mo, serving as Governor of Guangdong and Guangxi provinces, started to send government-sponsored students to study in Japan. There appeared a tide of studying in Japan. At the moment, many Xiangshan students went to Japan for study, such as, Zheng Anfu, Liu Shifu and Liu Juequn. Some organizations also prepared to send students to study in Japan. For example, in 1906, Xiangshan has sent some personnel to study in Japan. For they want them to be future teachers of their industrial schools lacking teachers at that time.
Xiangshan County has set up some industrial schools and established relevant regulations. The teachers shall be famous experts which are difficult to look for. So, they were suspended temporarily. And we first send twenty students to study in Japan. When they graduated, they can come back to serve as teacher. ${ }^{7}$

In other studies, we can also see Xiangshan students. For example, the following students studying navy in Japan were from Guangdong ${ }^{8}$ : "Table III", "Table IV" and "Table V"

TABLE III. Stage I (NAVIGATION)

\begin{tabular}{|c|l|l|l|l|}
\hline Name & \multicolumn{1}{|c|}{ Time of enrollment } & \multicolumn{1}{|c|}{ Graduation date } & Native place & \multicolumn{1}{c|}{ Remark } \\
\hline Xiao Baohang & Nov. 1, 1909 & Nov. 14, 1910 & $\begin{array}{l}\text { Served as president of } \\
\text { Guangdong Navy School }\end{array}$ \\
\hline
\end{tabular}


TABLE IV. Stage II (NAVIGATION)

\begin{tabular}{|l|l|l|l|c|}
\hline \multicolumn{1}{|c|}{ Name } & \multicolumn{1}{|c|}{ Time of enrollment } & Graduation date & Native place & Remark \\
\hline Zhuo Jinwu & Apr. 28, 1910 & Apr. 15, 1911 & Xiangshan & $\begin{array}{l}\text { Served as Navy Camp Training } \\
\text { Instructor in Chefoo in 1924 }\end{array}$ \\
\hline
\end{tabular}

TABLE V. StAGE III (NAVIGATION)

\begin{tabular}{|c|l|l|l|l|}
\hline Name & \multicolumn{1}{|c|}{ Time of enrollment } & Graduation date & Native place & Remark \\
\hline Zeng Guanglun & Nov. 1, 1910 & Nov. 5, 1911 & Xiangshan & \\
\hline
\end{tabular}

Graduated from mercantile marine school and didn't enter into naval gunnery school again after returning back.

\section{Zheng Zhonglian, Guangdong Xiangshan}

The students studying navy in Japan from Hunan and Hubei were the most, and Guangdong had 16, ranking third.

During the period of the Republic of China, there were still a lot of students who went to Japan at their own expenses, such as Yang Pao'an. Due to the statistical restrictions, the number of students studying abroad is not very clear.

\section{STUDENTS STUDYING IN JAPAN FOUNDED XIANGSHAN TEN-DAY TO PROPAGANDIZE NEW LEARNING AND REVOLUTION}

The number of Xiangshan students studying in Japan was large. After they finished their studies, they returned to their hometown to publicize the new learning, which produced a great influence in the local society. In 1905, Lin Junfu, a student in Japan, founded the "Awake Group" School in his hometown. Awake Group School set ceremony and abolished the emperor tablet, and also replaced the rite of thrice kneeling and nine times bowing with single bowing. Zheng An'fu, a student in Japan, established a school for women, named "Same Enmity". He also wrote a poetic couplet: "we are family. The governors of Man people and the foreigners all are our mutual enemies", hanging on gate of the school. ${ }^{9}$

In 1908, Zheng An'fu and Lin Junfu founded Xiangshan Ten-day, starting publishing from August 21st. It was aimed to wake the soul of the nation, carry forward mores, cut off people pest and cleanse corrupt. It has played a good role in supervising local administration, altering social customs, improving industry and collecting literature. The content of newspaper includes original articles, news commentary, local news, Chinese and foreign novels, stories, literary garden, collection, Xie Sou, miscellany, investigate, Xiangshan literature record, pictures, cartoons and so on. Readers of Xiangshan Ten-day were not only their local people but also from many domestic and foreign big cities, including Shanghai, Tianjin, Hankou, Hang Kong, Macao, San Francisco, Honolulu, Vancouver and New York.

Articles published in Xiangshan Ten-day advocated revolution and democratic politics and fought against local tyrants and evil gentry. It thought the gentry power hindered the realization of democratic politics. Only by overthrowing it, can we realize democratic politics. It also thought democratic politics was a good way to fight against gentry power. It advocated equality between men and women and opposed discrimination against women. The way to achieve equality between men and women is to set up schools for women and help them receive education. They also plead against exorbitant tax levies. The newspaper published articles advocating cutting braids, calling on people to eliminate doubts and cut off the braid. Influenced by the newspaper, the county established a number of braid-cutting societies and formed a new style.

It also reported news of revolutionaries. For example, Liu Shifu assassinated Guangdong navy commander-in-chief in 1907. But failed and he was arrested in Xiangshan Prison. Chief Editor Zheng An'fu and Xiangshan intellectual circle have bailed for many times and finally he was released in 1909. The newspaper published and commented on the behavior of Liu Shifu. After of failure of 3.29 uprising in Guangzhou, they also repeatedly published the news and proclaimed the spirit of them taking death calmly. After the Wuchang uprising, the news was published to introduce the progress of the incident to people.

It also reported the news of students studying in Japan, coming straight to the stage and promoting the revolution:

Antang Guangshan Medical Bureau raised money by acting. They scheduled to start on the evening of 8th in Chinese calendar. But because of chaos and debt default, there was no way to play. Actors have been ready and audiences have come. At the moment, it coincides with the return of oversea students. Someone suggested to invite them to give a speech. The majority approved. So, they opened lights and all actors and relevant personnel came on stage. Lin Xichun announced the reason of delay. It calmed audiences temporarily. Then he told the public the reason to appease the anger and asked oversea students to deliver speech for audiences. Then Lin Guiyan, Lin Bokang, Lin Shouchun, Lin Xiqi, Lin Xiyang and Lin Zhanpeng gave a speech on stage in succession. They delivered their opinions and were of same purpose. Up to midnight, the crowds dissipated. That night there were both men and women audiences. Warm applause can be heard without end. ${ }^{10}$

\section{STUDENTS IN JAPAN INSTIGATED AND LED THE XIANGSHAN UPRISING IN 1911}

Before the Wuchang uprising, Lin Junfu and Zheng An'fu have set up organs in Macao. They secretly carried out revolutionary work and began to instigate the new army in Qianshan as well as the patrol camp in Shiqi, and contacted gentlemen in Shiqi.

At the time some revolutionists, including Su Mozhai, Liu Ximing and Chen Zijue, taught in Qianshan Gongdu Primary School in order to hide their identity and do revolutionary work. They came back from Japan. The new army was 
influenced by their revolutionary work. On October 15th, Qianshan New Army started an uprising and gained victory without bleeding. Immediately they were ready to enter Shiqi. At same time, Lin Junfu and some other people thought it was urgent, and they returned to Shiqi to convene meeting and decide to uprise on this very day. The armies of various regions marched towards Shiqi. Shiqi defenders didn't defend because of the failure of the oppression on Xiaolan Uprising. The chief commander escaped and there was no lord in the army. The county leader saw the hopeless situation and surrendered. The uprising succeeded. On 17th, they organized a government and Zheng An'fu and some others were responsibly for civil affairs. After the victory, they changed to Xiang Army led by Zheng An'fy and Lin Junfu and started to support Guangzhou. Later they took part in the northern expedition.

\section{STUDENTS STUDYING IN JAPAN PROPAGANDIZE ANARCHISM IN XIANGSHAN COUNTY}

Anarchism thought has emerged in Europe from the 18th Century to 19th Century Europe and became a political theory in Proudhon. Its main representatives were Bakunin and Kropotkin. This trend was introduced in China from the early 20th Century. It has been very popular. Many people accepted the trend of anarchism and actively promoted it. Liu Shifu, a Xiangshan student studying in Japan, was one of the important representatives. Liu Shifu (1884 - 1915), formerly known as Shao Bin, named Sifu when studying in Japan. After the establishment of Republic of China, he gave up his name and changed into Shifu. He passed the imperial examination at the county level in 15 . In 1904, he went to Japan to study, and was influenced by the anarchist and the "empty party" of Russia. In the spring of 1907, he was accidentally injured when making a bomb in Guangzhou, and arrested. In the summer of 1909 , he was rescued by Zheng Bi'an, and went to live in Hongkong. In Hongkong he devoted himself to the study of New Century and preached anarchism. In the spring of 1910, he and Xie Yingbo, Gao Jianfu and Chen Jiongming established "China Assassination Mission" in Hongkong to continue without-government assassination activities. In May 1912, Liu Shifu and Zheng Bi'an et al initiated an organization Huiming School in Guangzhou to propagandize anarchism. This is the first anarchist group in China. They printed anarchist pamphlets published in Paris. They also printed "New Century Series" and "Anarchism Speech". Then they integrated them and published "Anarchism Masterpiece Series" in order to promote anarchism ${ }^{11}$. In July of the same year, he and Zheng Bi'an, Mo Jipeng and others founded Heart Society in Guangzhou Dongyuan, as the core group of anarchist connection. In 1913, he founded Huiming Record (altered into Civil Voice from the third issue). In July and August, Guangdong Governor Long Jiguang banned Civil Voice. It was forced to cease publication. In 1914, Liu Shifu moved to Shanghai with Heart Society. In July, Liu Shifu and others founded the "Anarchist Communist Comrade Society" in Shanghai, advocating economic and political absolute freedom. He died in Shanghai in March 1915.
Liu Shifu's anarchism was echoed in his hometown, and there was an anarchism propaganda newspaper in Xiangshan. The existing incomplete newspaper Tie Sheng has reflected it. It has newspaper from Mar. 9, 1921 to Jul. 2, 1921. It was founded in May 1920, and was a newspaper advocating anarchism communist. In its supplement Zheng Zheng Lu, Chief Editor Lang Ou prefaced:

I'm Lang Ou. I am obsessed with anarchy. I devote myself to carry forward anarchy in my life. In spring, I take charge in edition of Tie Sheng. It has published Huanli Cuijing Collection. I felt that its philosophy was very good, and I was touched greatly. So, I published it on Tie Sheng inch by inch. ${ }^{12}$

The newspaper also published Kropotkin Biograph for eighteen consecutive days. It also published articles of "Cold Ash", an anarchist in Xiangshan. In March and April, it established Taoran Labor Body (Lifa Union) and Gelv Labor Body. At the end of June, it organized Tongle Society among weedtree workers. ${ }^{13}$ This newspaper has been far to Kuala Lumpur, Singapore, Siam (Thailand), as well as Hongkong, Macao, Beijing, Shanghai, Guangzhou and other places. It has a wide range at home and abroad. It also shows that anarchism has a great influence on the area of Xiangshan. We can also see the influence of students studying in Japan in local society from one aspect.

\section{STUdENTS STUdying IN JAPAN PROMOTED WORLD LANGUAGE IN XIANGSHAN COUNTY}

Esperanto is an artificial language, and its transmission in China is connected with anarchism. It was introduced into China by oversea students. Liu Shifu was an enthusiast. In the fall of 1912, Liu Shifu initiated the study of Esperanto in Guangzhou and served as vice president of the Guangzhou Esperanto Society. Zheng An'sfu and Zheng Peigang were active learners in Xiangshan. They studied in Guangzhou in 1912. Zheng An'fu and Liu Shifu were early advocators of the Esperanto Movement in Xiangshan. Zheng Daoshi (magistrate of Zhongshan County in 1926) also advocated Esperanto. In 1913 he invited Huang Zunsheng to Xiangshan County to teach Esperanto. In the beginning, it was in his home at the south gate of Shiqi, Gonghe Lane. Later it was moved to Liu Shifu's study room, at the east gate. There were twenty to thirty students and all of them are celebrities in the education circle of Xiangshan. ${ }^{14}$

In 1920s, some revolutionists used Esperanto to engage in revolutionary activities. During the Anti-Japanese War, some people also used Esperanto to engage in Anti-Japanese activities.

\section{OVERSEA STUDENTS FROM JAPAN SET UP EDUCATION IN XIANGSHAN COUNTY}

Oversea students actively set up school in hometown for the benefit of local people. For example, Wei Bangping was very concerned about the education of his hometown. In 1911, Wei Bangping founded a primary school in his hometown of Hongmiaofang. It was suspended due to flooding in 1912. He sponsored many materials and recover it in 1921. At the 
beginning of the first batch of students, he sent a uniform to each student. ${ }^{15}$

Liu Juequn, a student from Japan, served as president of Danmin Primary School in Zhongshan Shiqi after his husband died in his revolutionary work. The school was established in a suburb temple in Shiqi. With no houses nearby it was surrounded by fields. Students of Danmin School were children of poor labor people. The school often lacked funds and had many difficulties. So, she should managed school and raise funds. In 1923, Mr. Sun Zhongshan returned from Shanghai to Guangdong. He personally ordered Committee of Zhongshan County to appoint Liu Juequn as president of Women's Normal School of Zhongshan County.

\section{CONCLUSION}

The number of Xiangshan students studying in Japan was large, and they have played an important role in various industries. Though most of them are unknown, they have made no small contribution to their hometown and the society. They founded newspaper, propagandize new learning and revolution. Actually they have left very previous history data for us. In the late Qing Dynasty and the early Republic of China, a lost of archives all over the country were badly preserved and seriously damaged. These newspapers and magazines have reported social conditions at that time. They have made a great contribution to protect county-level literature. They propagandized revolution and instigated new army which is even earlier than Guangzhou. It is the result of students who have studied in Japan. They set up new primary schools, propagandized new learning and transformed local education, making a great contribution to their hometown's modernization. All in all, the students studying in Japan have had a great influence on modern Xiangshan society.

\section{REFERENCES}

[1] Chen Xuexun and Tian Zhengping. Educational History of Modern China - Studying Abroad. Shanghai Education Publishing House, 2007, Page 46.

[2] Chen Xuexun and Tian Zhengping. Educational History of Modern China - Studying Abroad. Page 47.

[3] Tang Zhijun. Collection of Kang Youwei's Political Comments I. Zhonghua Book Company, 1981, Page $301 \sim 303$.

[4] Fang Zhaoying. List of Oversea Students at the end of Qing Dynasty. Central Research Institute of Modern History, 1962, Page $49 \sim 52$.

[5] (Qing) Yu Baoxuan. Imperial Xu'ai Essays. Taiwan Student Publishing House, 1965, Page 1465.

[6] Fang Zhaoying. List of Oversea Students at the end of Qing Dynasty/ First Draft. Page $6 \sim 16$.

[7] Oriental Magazine, Vol. 3, 5th Issue, Page 102.

[8] Huang Fuqing. Students Studying in Japan at the end of Qing Dynasty, Central Research Institute of Modern History, 1975, Page $45 \sim 51$.

[9] Zheng Peigang. Xiangshan Ten-day and Founder of Zheng An'fu. Guangzhou Literature History. Series 25.

[10] Oversea Students Taking the Stage. Xiangshan Ten-day, 98th Issue, Page 75. Quoted in Huang Jianmin's Contrast of Xiangshan County before and after 3. 29 Uprising in Guangzhou seen by Xiangshan Tenday. Modern China, Series 18.
[11] Xu Shanguang. Comments on Liu Shifu's Anarchism during the Revolution of 1911. Journal of Wuhan Teachers College (PHILOSOPHY AND SOCIAL SCIENCE EDITION), 3rd Issue, 1981, Page 34.

[12] Li Jian. A Remnant of Xiangshan Tie Sheng. Zhongshan Literature History. Series 50.

[13] Li Jian. A Remnant of Xiangshan Tie Sheng. Zhongshan Literature History. Series 50.

[14] Chen Yongxi. Early Esperanto Activities in Zhongshan. Zhongshan Literature History. Series 17.

[15] Wei Yongyi. Wei Bangping's Life. Zhongshan Literature History. Series 11.

[16] Ruan Shaoxian. Recalling My Mother Liu Juequn. Zhongshan Literature History. Series 22. 